Article

\title{
The Passion of Christ on Television: Intertextuality as a Mode of Storytelling
}

\author{
Stefan Gärtner \\ Department of Practical Theology and Religious Studies, Tilburg University, P.O. Box 90153, NL-5000 LE Tilburg, \\ The Netherlands; s.gartner@uvt.nl
}

Received: 2 October 2020; Accepted: 9 November 2020; Published: 13 November 2020

check for updates

\begin{abstract}
The Passion is a contemporary performance of the passion of Christ live on stage, combined with pop music, city marketing, social media, and entertainment. The result is an encounter between the Christian gospel and traditional elements of devotion like a procession of the cross on the one hand, and the typical mediatization and commercialization of late modern society on the other. In this article, I will first briefly describe the phenomenon, including the different effects that the event has upon the audience and the stakeholders and benefits it has for them. It is one characteristic of The Passion that it allows for a variety of possible approaches, and this is, at the same time, part of its formula for success. Another characteristic is the configured intertextuality between the sacred biblical text and secular pop songs. In the second section, I will interpret this as a central mode of storytelling in The Passion. It can evoke traditional, but also new, interpretations of the Christian gospel. The purpose of the article is to interpret The Passion as an expression of constructive public theology. It is an example of how the gospel is brought into dialogue with secular society.
\end{abstract}

Keywords: passion play; The Netherlands; public theology; intertextuality; The Passion

\section{Introducing The Passion}

The television program The Passion is an example of public theology. This concept is not about preaching the gospel to society, but bringing it into dialogue with and in society. The point of departure is the incarnational character of the Christian faith, which transcends the boundaries of the church (Day and Kim 2017). Traces of God can be found in the secular world, because he honored the world through his self-revelation in Jesus Christ. However, this is not first and foremost about mission, but rather about a mutual dialogue. Not only the world is placed under criticism, but also the church and theology. They in turn benefit from their contact with different social systems and with all aspects of life. The Christian faith is again decontextualized. The concrete result can be a form of constructive public theology (Breitenberg 2003, pp. 64-65), such as an event like The Passion, where the Christian narrative melds with secularity.

\subsection{The Special 2020 Edition}

The Passion was originally developed by the BBC in 2006 under the title of Manchester Passion, with a live production of the Christmas story (Liverpool Nativity) the following year (Dowell 2006). The idea was adopted in the Netherlands in 2011, and it has been revised and adapted ever since. In contrast to other countries, it has in the Netherlands become an annual event, held on Holy Thursday. It is staged each year in a different city. The Dutch format has been successfully exported to other countries. Thus, the American broadcaster Fox performed The Passion live in New Orleans on Palm Sunday 2016 (Andreeva 2015). The production was relayed worldwide via the streaming service 
Netflix. ${ }^{1}$ The event has been organized every second year in Belgium since 2014, and a second edition has been planned in the UK for 2021.

A performance of The Passion was set up in Germany for the first time in 2020 (Nelissen 2020). The original idea for the current article, on the occasion of a congress at Dortmund University, was to compare the German and the Dutch editions. This appeared promising, since the religious fields in both countries seem similar at first glance, which is all the more reason to analyze the differences in the two broadcasts and to ask what could explain these (Gärtner 2017a, pp. 208-15). However, the coronavirus put a stop to this plan, as the German edition was canceled. We decided to look instead at the 2017 Dutch production, since the 2020 Dutch version of The Passion was held in a unique format. It was the tenth production in the Netherlands, allowing the broadcaster to use material and clips from past editions and to integrate these into a live performance in a studio location. Very suitably, given the fact that the coronavirus was dominating world news at the time, the title was Now Give Me Your Fear. ${ }^{2}$

After an opening scene featuring deserted streets, the presenter said that "tonight, perhaps more than ever, the Netherlands is in need of a story about hope, faith, and love." The age-old story of the passion of Christ suddenly came very close to people. In the ensuing broadcast, the current crisis and the threat that the virus posed to all Dutch citizens were repeatedly linked to this event: like all of us today, Jesus Christ experienced loneliness and fear, which he overcame through his sacrifice and his love. He shared our suffering, but, according to another statement made during the performance, "if death can be overcome, then nothing is impossible anymore". The cross was not the end, but a new beginning. Jesus is called "savior of the world", who "faced his fear out of love for humankind".

These are central messages from the gospel that have been passed down through generations of believers. Whether, and if so in what way, the viewer today still considers this story to be credible, is explicitly left to the viewers themselves to decide. The underlying principle of The Passion is "believe it or not". This is one of the reasons why the event is also popular among non-Christian or secular Dutch people (Bernts and Berghuijs 2016, pp. 74-75).

The 2020 edition of The Passion in the Netherlands thus told the well-known story in line with an orthodox theological program, according to which Jesus Christ died on the cross in solidarity with the people and ultimately for them (Korthaus 2007). The current significance of this event lies in the possibility to identify the experiences of that time with those of today.

Other, non-Christological, interpretations of the Covid-19 crisis were possible as well. Mary, the mother of Jesus, stands under the cross, for instance, and sings about how to feel close to someone who can no longer be present: through mutual longing for each other. This could be applied to Jesus, but also to people in quarantine. In the performance, Pilate is the prototype of someone who, like us, is trying to keep control of his life in times of crisis and upheaval. Additionally, when Jesus and his disciples arrive in Jerusalem, the following words are sung: "don't let my hand go, you don't have to do this alone". Repeated appeals are included for people to stand together, to remain positive, and to take special care of people who are at risk. Of course, there are worries and fears, but also many examples of commitment and solidarity—this is what the audience is encouraged to build on in the present crisis.

The title of the 2020 event was derived from an eighties hit by the popular Dutch folk singer André Hazes. Later, the equally famous singer Guus Meeuwis issued a cover version of this song. The original lyrics were written by Michael Kunze for the Austrian singer Udo Jürgens in 1982. The chorus line is: "Now give me your fear, I'll give you hope in return. Now give me the night, I'll give you the morning in return." This brings us to the central artistic device of the passion of Christ on Dutch television: the combination of the gospel and contemporary popular music. That is why we have chosen to analyze the phenomenon from the perspective of intertextuality.

\footnotetext{
See https://www.youtube.com/watch?v=Rp8_95gNcko.

See https://www.thepassion.nl/geef-mij-nu-je-angst.
} 
This song was also performed in an earlier edition of The Passion, and it was reused in 2020. In the earlier production, it already "elicited a lot of emotions during the performance ( ... ). And rightly so. The content of this song is suitable for conveying the story of Jesus' passion. He took away our fear, so that we can receive hope in its place" (Koster 2017, p. 16). This message was reinforced by combining footage of the song as it was performed by the risen Christ from the earlier edition with contemporary homemade videos of ordinary Dutch citizens and former actors from The Passion. At the end, they all sing the song together. The videos featured individuals, but also groups of professionals such as firefighters, teachers, doctors, and geriatric nurses, who played a particularly essential role during the corona crisis. Their commitment was praised repeatedly throughout the broadcast. Additionally, audience members were asked to share their fear of the virus, but also their hope. These texts were then read during the production and selected video messages were shown.

\subsection{The Phenomenon Itself}

The Passion is a mixed-media project that uses the format of a huge entertainment event, but also includes classic elements of a passion play. The passion of Christ is transferred to the secular domain and there takes on new shape (de Groot 2019, pp. 418-21). In the process, certain contents and practices of the original context of the story remain, although in an adjusted form.

The Dutch version of The Passion is organized by the Christian television networks in collaboration with the mainstream churches and the Netherlands Bible Society (Nederlands Bijbelgenootschap). After a moderately successful start, The Passion has gone on to become one of the best-watched television programs in the Netherlands. In 2015, it reached the peak of 3.6 million viewers; in 2017, there were 3.1 million viewers, which amounts to a market share of 44 percent (Mediacourant 2017). The special edition in 2020 was also a success, with 2.8 million viewers and a market share of 42 percent, especially when these numbers are compared with those for the previous year's edition: 2.4 million viewers and a market share of 40 percent (Mediacourant 2020). Half of the Dutch population has at one point in time watched an edition of The Passion, and 40 percent of church members watch it regularly. Even among people who consider themselves to be secular, the percentage that has seen an edition of The Passion at least once is at a third (Bernts and Berghuijs 2016, pp. 74-75).

Critics have argued that the combination of popular culture, entertainment, and marketing on the one hand, and traditional biblical and liturgical elements on the other, is skewed to the disadvantage of the latter. Others regard it as religious kitsch (de Groot 2015). Additionally, orthodox Calvinist groups have protested what they believe to be an inappropriate exploitation of the passion of Christ. They regard The Passion as a sacrilege.

Although non-Christians give The Passion a relatively positive evaluation (Bernts and Berghuijs 2016, p. 76), only few of them report taking a greater interest in the Christian faith after the event. Commentaries about it on social media like Facebook or Twitter are often about aspects like connectedness and togetherness (Jansen 2017). Only relatively few posts contain references to the passion of Christ itself or to the Bible. Nor has church attendance increased because of The Passion (Stassen and Helm 2016, pp. 27-29).

The event itself consists of an approximately 90-minute live broadcast of the passion with orchestra and choir from a central stage in the host city. Prepared shots and live connections are also displayed, on big screens on the spot and on television. ${ }^{3}$ The Last Supper, for example, is sometimes staged in a local restaurant beforehand, and footage of this is then shown. There is a procession with a six-meter-high cross that is illuminated with white neon lights. The color white also dominates the scenic design and the musicians' clothes. This color refers to the Dutch name for Holy Thursday, Witte Donderdag, meaning "White Thursday".

3 See https://www.thepassion.nl/vorige-edities. 
The procession is limited to 1000 participants. The cross is carried by volunteers who have applied to do so for personal, often also explicitly religious, reasons (Klomp and Veldsman 2017, pp. 25-28). The cross is integrated into the events on stage once it arrives there, and it has a strong dramaturgical effect. Furthermore, the cross often dominates media reporting about the program the next day, Good Friday (Fijen 2015, pp. 38-39). As a result, the central symbol of Christianity is prominent in what is otherwise a strongly secularized public sphere.

There is no depiction of the crucifixion. All elements of suffering as they appear in the biblical passion of Christ, such as the scourging at the pillar or the last hours on the cross, have been excised. At the moment that corresponds to these scenes, details are shown of images of the crucifixion from art history. After the first performances in the Netherlands, viewers criticized the staging of the crucifixion for being too radical. By contrast, the crucifixion had an important function in historical passion plays (Schulze 2012, pp. 79-82). Ever since the transition from the dominance of images of Christ as the triumphant Pantocrator to that of the suffering Ecce Homo, and with the increasing impact of the cross in Christian spirituality in the 13th and 14th centuries, the pain of Jesus has been explicitly depicted. The passion plays provided an opportunity to feel compassion with Christ (Barton 2016, pp. 281-306). The aim was to effect a momentous realization of salvation, from which not only the performers, but also the spectators, could benefit by joining in it (Dauven-van Knippenberg 2003).

During The Passion, a presenter acts as the evangelist, who not only narrates the passion, but also comments on it and gives an updated interpretation of it (van den Hemel 2020, pp. 80-81). The text is derived from the comprehensible Bible in Present-Day Dutch (Bijbel in Gewone Taal), published by the Netherlands Bible Society. The text does not conform to one single passion narrative, but presents an integrated story in the style of a gospel harmony. That was also the case in many historical passion plays (Schulze 2012, pp. 80-82).

This makes it possible to omit certain elements of the story and apply new emphases. One example concerns Jesus' mother Mary, who plays a greater role in The Passion than she does in the Bible (den Braber 2012, pp. 39-42). The same can be said of the so-called "Mary's lamentations" in traditional passion plays (Schulze 2012, p. 136). These were not derived from the Bible either. Furthermore, the Easter event is staged in The Passion, a feature that was similarly not unusual in historical passion plays. The appearance of the risen Christ concludes The Passion in a positive way. The organizers apply different emphases each time by adjusting the dramaturgy (Klomp 2015a): it makes a difference whether the risen Christ appears somewhere high up, like on a church spire, or whether he presents himself standing among the spectators as a living man.

The biblical texts are mixed with humorous comments by the narrator, which are a consistent element: "Pilate-no, not the inventor of the fitness routine" (Pilates). This creates an ironic distance that puts the story of the passion of Christ into perspective and enables the audience to distance itself from what is happening on stage. That is at least what can be gathered from comments about the broadcast on social media (Klomp and Meulen 2017, pp. 393-97).

The storytelling repeatedly refers to the hosting city and to the current political situation. For instance, viewers associated the orange overalls in which Jesus and Barabbas already appeared before Pilate in the Manchester Passion with the prisoners in Guantanamo Bay or with videos of beheadings by Islamic State (IS) (Klomp et al. 2018, pp. 210-12). Furthermore, there are real police officers involved in the arrest of Jesus. Before the performance in Germany, the authorities refused permission for this; they did not wish the police to appear as the henchmen of a rogue regime.

We have already addressed another artistic element of The Passion: the connection between the biblical story and well-known Dutch secular songs that were not written or composed for the event itself. The organizers had recourse to (textually sometimes slightly modified) pop songs to make the message of the production easy to grasp. This builds a bridge "between the suffering of Christ as it is told by the churches and the experiences of a new, often secular generation. This generation is indeed receptive to existential questions, but does not understand the language of church and faith anymore" (Fijen 2015, p. 38). 
Nor are the actors and singers expected to be religious, but they have to be willing to identify with the event, at least in a general sense. Their participation has proven to be an effective advertising strategy. In 2015, for example, there was debate about whether an alleged criminal would be a suitable actor for the role of Barabbas. This was discussed in talk shows, and the biggest daily newspaper of the Netherlands (De Telegraaf) dedicated a survey to the topic (van der Meulen 2017). The public announcement, a few weeks before the event, of which prominent stars have agreed to participate in that year's edition of The Passion is also part of the marketing concept.

In addition, the event is promoted on social media. This multimedia access permits active co-creation by the audience (Klomp and Meulen 2017, pp. 392-96). Since 2014, it has been possible to take part virtually in the procession of the cross and to share your own personal point of view with others. In 2020, almost 20,000 people made use of this possibility. It acquired a special significance that year, because the procession could not be realized on-site.

During Lent, people are invited to prepare for the event in WhatsApp messages featuring inspiring texts and clips. A special hotline staffed by the Netherlands Bible Society answers queries about the Book of Books. The website of The Passion offers possibilities for people to get to know the Christian faith or to deepen it. Schools are also provided with relevant material for religious education classes. There is a newsletter, and anyone interested can keep informed about all new developments regarding the event via Twitter.

This mediatization makes The Passion accessible to those who cannot be present at the event on-site. Moreover, the use of social media expands the one-way communication, which is the hallmark of classical electronic media like television. The audience no longer consists of just consumers, but people can also participate as prosumers. Additionally, the broadcast is watched by people together in parishes, monasteries, cinemas, or retirement homes. This is sometimes embedded in gatherings or liturgical celebrations ('t Mannetje 2015). Thus, the event not only uses modified Christian elements, rites, and language. The story of the passion of Christ as transformed in a secular context in this contemporary passion play also sometimes returns to church (Klomp and Barnard 2017, pp. 249-50).

\subsection{Different Approaches to the Event}

What are the effects that the program has on the audience and stakeholders, and the benefits it has for them? Typically, The Passion attracts tiered participation for a variety of motives. The different ways in which the participants perceive it make it a hybrid and altogether fluid event (Gärtner 2017b; Klomp and Barnard 2017). Five groups can be distinguished. Firstly, there are the viewers, who watch the program on the television, and the spectators along the procession route or in front of the stage. The latter enjoy the performance as a crowd and can share this experience with others through selfies, videos, or comments on social media. Moreover, it is possible to become a participant on-site, although in a role that, from the perspective of the gospel, is problematic. On the big screens, the audience is encouraged, as a crowd and therefore in the role of the so-called "Jews-turbae" (von Fischer 1997, p. 34), to shout "Crucify him!" and to demand the release of the murderer Barabbas. ${ }^{4}$

Secondly, there are the performers, who talk about the production in the media beforehand and afterwards. They give their views on what The Passion means to them, but also more generally what the Bible, religion, or spirituality mean to them personally. This is an important contribution to the authenticity of the storytelling. In the past, the morality of different actors who played Barabbas or the explicitly articulated unbelief of a performer who played Jesus caused public debate (Klomp et al. 2018, pp. 213-14).

Unlike the singers and actors, the third group, consisting of the organizers, sees the event as a means of communicating the Christian faith in a secular society. Moreover, the success of The Passion

4 Historical passion plays often displayed anti-Semitic tendencies (van den Hemel 2020, pp. 30-32; Schulze 2012, pp. 213-16). From this perspective, the participation of the audience in the conviction of Jesus can be seen as problematic. 
is likely to positively affect the image of the Christian television broadcasters, which they need as membership organizations (Gärtner 2017a, pp. 61-63). The churches may have the same expectations with regard to the event.

The prominence of the host city and the connectedness of the citizens with the city is the central motive for the hosts of The Passion. The broadcast uses prominent sights in the city as its setting. The performance itself is an additional source of income for the local economy and an opportunity for marketing. Each year, there are multiple side events, both of a commercial and of a non-commercial nature, such as the so-called After Passion organized by local churches (van den Hemel 2020, pp. 84-91).

Fifthly, there are the virtual and real participants in the procession. They have reported personal motives for doing so including explicitly Christian convictions: "By engaging in this procession ritual, participants very often turned out to actively connect themes related to the procession (e.g., suffering, pain, cross, sacrifice, death) to events they (have) experience(d) in their personal lives ( ... ). In doing so, they may have encountered the divine in a new way" (Klomp and Veldsman 2017, p. 29).

These different types of participation can come into conflict with each other. For instance, the question was raised whether the financial support that the host city offers to the performance of the passion of Christ does not in fact undermine the separation of church and state. The organizers' point of view, that the event is a missionary opportunity for the Christian faith, seems irreconcilable with the religious neutrality of the Dutch state. Despite the fact that the event had a positive effect on the reputation of the city involved, there were also critical voices from local entrepreneurs (Hoondert and Klomp 2014, pp. 323-27).

Even within the groups mentioned, reasons for taking part are multi-layered. In other words, there is not one single perspective on this passion play that all people in the same group share. People have their own view on what is shown on stage and create their own interpretation of the performance. This is stimulated explicitly by the artistic and dramaturgic design of The Passion, for instance by situating the event in the everyday world, by ironically reframing the biblical narrative, or by the references to contemporary history.

Different approaches are apparent, especially within the group of spectators. The spectators' motivations for participating are very diverse, ranging from wishing to take part in a catechetical opportunity, searching for spiritual experiences and curiosity, to wishing to enjoy a free outdoor concert. The visitors on site perceive The Passion as a collective experience, while each one has their own individual perspective on it: "The common ground is the collective (but not uniform) participation in the event, while the appreciation and appropriation are very different and the meaning is multi-layered" (Klomp 2012, p. 52).

Similar nuances occur when it comes to deciding whether or not to join the procession. This is sometimes "an expression of attachment to the tradition of one's parents and grandparents, to which one is not linked personally. It is about community with other people who are also participating in The Passion. It is about a connection with the history of someone 'who was a good man' (Jesus), to express that one wants to do good. It is about commemorating deceased relatives in the form of a special nocturnal walk ('Grandma, I love you and I know that you are looking down on me from heaven'). It is a silent demonstration against pointless violence in society, the experience of 'the other' that is bigger than us, or it is an experience of beauty. And it is also still a modern way of remembering Jesus, his suffering, death and his resurrection" (Klomp 2015b, pp. 137-38). As empirical research has shown, these are some of the motives people have to actively participate in the procession of the cross (van den Hemel 2020, pp. 70-96; Klomp and Veldsman 2017).

Passion plays are an opportunity to transcend everyday reality during the performance (Schütz 2020). In a post-secular society, such transcendental experiences are framed in multiform, individualized, and selective ways. The framing is no longer simply religious, and it is also less traditionally Christian than it was in the past. The resulting pluralism strengthens the hybrid and liquid nature of the event (Klomp and Barnard 2017, pp. 245-50). 
The organizers contribute to this effect by giving the story of the passion a different focus each year. In 2020, the emphasis was on helping to overcome the coronavirus crisis in the Netherlands. Something similar happened in Enschede in 2015, when the performance recalled a fireworks disaster that occurred in that town 15 years before. In other editions, the passion of Christ was staged as a conflict between the established order and the supporters of the Nazarene who longed for change, or it was about migration, the core message being that prejudices in society should be overcome. This was, among other things, expressed through a song about someone being stabbed on the street. This song is the only one that is sung every year during The Passion. Like the repetition of other elements, this contributes to the ritualization of the event (Fijen 2020). During the scene of the trial against Jesus, Jesus and Pilate together sing about leaving behind all black and white contrasts. They appeal for an alternative way of thinking, "with the color of the heart".

\section{Configured Intertextuality}

\subsection{Intertextuality between the Sacred and the Secular}

This last example brings us to the central dramaturgic principle of The Passion. Every year it "consists of a unique and carefully composed blend of elements. This blend is comprised of secular Dutch popular music on the one hand, and the Christian/biblical narrative of the passion, on the other. ( ... ) The liquid nature of popular music culture-expressed by hit songs competing for the number one spot on the music charts-intersects with the biblical narrative. The blend is relentlessly temporary and made for a specific performance; afterwards it dissolves" (Klomp and Barnard 2017, p. 247). To interpret this blend as a mode of storytelling, we will apply a narrow understanding of intertextuality that leans on the relation between sacred and secular texts. In doing so, we will regard The Passion as an expression of public theology.

The term intertextuality was defined by Julia Kristeva (1972), following Michail M. Bachtin. It generally means that texts, which can also refer to a culture or a society, always stand in relation to other texts that mutually interpret each other. Every text is therefore a mosaic of quotations, since words, as it were, still carry the meanings within them that they had in previous texts. This process continues endlessly.

A narrow understanding of intertextuality speaks only about those references between narratives that the author intended, e.g., between the Old and the New Testament. Due to the influence of structuralism, this type of chronological and explicit referentiality has been expanded to include all relations between texts. Structuralism is based on the assumption that phenomena do not occur in isolation, but are linked to other phenomena. Therefore, not the things themselves must be considered, but the relations between them. No sign can be understood without reference to other signs (Schneider 2018). Each text has an intertextual potential, which it does not develop on its own and which can never be settled by some final interpretation. This qualifies the roles of the author and the reader, as well as the supposed hierarchies between high-level and everyday language, or between sacred and secular texts. Instead, the text itself is given center stage. It is engaged in permanent exchange with other texts and with the whole of a culture.

This theory is particularly important for The Passion insofar as this production uses the intertextual characteristics of narratives as a creative means. It presents a combination of texts that would not normally be found in the same context. Well-known pop songs are covered and integrated into the biblical story, which itself is performed in a secular domain and is interpreted by the popular music (Hoondert and Klomp 2014, pp. 318-22). This configured intertextuality evokes reinterpretations and new understandings of the central Christian narrative of salvation.

At the same time, it is clear that the producers have no control over how their event is received. This is something we already pointed out in the last section: people develop their own perspectives on the performance. Furthermore, from an intertextual perspective, the boundaries between sacred and secular, between public and private religion, as well as between sophisticated and popular language 
are blurred (Dillen and Gärtner 2020; Engelke 2012). Instead, the production is characterized by a deliberate mixture of these opposites, which seem to be clear and self-evident at first glance. When seen from the perspective of intertextuality, this clarity and self-evidence are strongly relativized.

It was not unusual even for historical passion plays to use a blend of various texts, although, overall, they all featured within a Christian context. These plays were initially bilingual, partly in Latin and partly in the vernacular. After the disappearance of the bilingual format, the liturgical parts were still apparent as a body. They were complemented by non-biblical texts as well as by hymns or interpretative commentaries (Polheim 2006). The Passion thus has its predecessors also when it comes to configured intertextuality.

The historical passion plays gradually moved away from their liturgical origins. The passion plays of the old church had their place in the liturgy of Good Friday and Easter as chant or recitation. Later, "para-liturgical passion plays" (von Fischer 1997, p. 28) evolved, as participants and dramaturgical elements increased, and as the music became more complex. In the 18th and 19th centuries, the break with the liturgy became complete. As a consequence, the mode of participation changed from the above-mentioned holistic sharing in the passion of Christ to a more distanced spectating and listening (Moser 1990). The musical passion was now performed in secular buildings or in churches converted into concert halls.

Hence, The Passion actually continues a long development of the passion play, out of the liturgy and into the public space (Schulze 2012, pp. 78-135, 227-31). Due to the intertextuality between sacred and secular texts as the dominant mode of storytelling, each year a variety of (re-)interpretations of the gospel is depicted on stage. We will examine this public theology by analyzing the 2017 edition that took place in Leeuwarden.

\subsection{The Passion Read Intertextually}

In 2017, the passion of Christ was told on Dutch television as a story that connects people in times of societal contrasts and tensions. Among these tensions was the view sometimes expressed by people from Friesland, the area in which Leeuwarden lies, that their voice is often disregarded by the rest of the Netherlands. However, as no one should be excluded during The Passion, the presenter spoke a few words in the local language, while some of the songs were in Frisian. The presenter promised in his opening lines that the audience would together experience a very old story ("older than the Rolling Stones") that had not lost any of its spirit and significance.

The opening song during Jesus' entry into Jerusalem was about the dawn of a new age, with the refrain: "It will get better,/if we join together, it will get better./And we know the morning is near,/and will be over quickly./We are greater,/together we are greater." (The Passion Leeuwarden 2017). ${ }^{5}$ The core message of this song, which, surely not by chance, was also used in the 2020 special edition, is that you are stronger if you stand together as a community. The biblical narrative of Jesus' triumphal entry into Jerusalem was updated by configured intertextuality. It became an optimistic story about a collective new beginning in the present-day Netherlands that the audience could experience on site.

Jesus and his disciples sang the song together. However, Jesus, of all people, sang the line quoted above alone: "Don't let my hand go, you don't have to do this alone" (The Passion Leeuwarden 2017). ${ }^{6}$ The connectedness between people as they were enjoying The Passion together could also be interpreted as feeling a sense of community with Jesus. This was therefore the overall message of the opening scene: on the one hand, unity among all members of Dutch society without prejudices and without excluding anyone, and, on the other hand, a theological statement-possible unity with the messiah.

\footnotetext{
5 "Het wordt beter,/met elkaar wordt het beter./En we weten dat morgen vlakbij is,/en zo weer voorbij is./We zijn groter//bij elkaar zijn we groter."

6 "Laat mijn hand niet gaan, je hoeft dit niet alleen te doen."
} 
This kind of reframing of the biblical story is often conveyed during The Passion through the poly-semantic imagery of the songs. Their theme of love, in particular, can be transferred to the relationship between the respective protagonist and Jesus. One example from the Leeuwarden edition is when Jesus' mother Mary sang: "Here is my hand, here is my heart,/I give my life to you./For long it was cold and dark, soon it will be a new day./The light will find its way, on the new day. ( ... ) There will be no new day that I will not be with you./No clock will tick for us in vain." (The Passion Leeuwarden 2017). ${ }^{7}$

Another effect of the event's typical intertextuality is similarly connected to the theme of romantic love: the reception of the biblical story is individualized. An example is, again, Mary, standing next to the cross and singing: "You kiss me, you calm me./You embrace me, you soothe me./You catch me, you long for me,/always still my fear./You call for me, you hear me./You save and disrupt me./Believe me, deprive me,/suffocate and numb me./You breathe and live me. ( ... ) Let me go,/I have to continue alone now./And hold on to me if necessary:/in thought. And I will search for you/in everything around me." (The Passion Leeuwarden 2017). ${ }^{8}$ The interpersonal dimension of the pop song is expanded by a transcendental dimension due to its performance during The Passion: the loved one can even be addressed in the afterlife. Conversely, intertextuality suggests a certain interpretation of the biblical story: it is possible to feel the ongoing presence of the crucified in the traces of the everyday world.

Another example of configured intertextuality in Leeuwarden was Peter's confession that Jesus is the messiah and Jesus' appointment of Peter as the rock foundation of the church. During the performance, the biblical narrative dissolved into an intimate friendship scene. Jesus and Peter withdrew from the crowd and sang the song "I cry only when I'm with you" in a duet. Its basic message is that only in the presence of a friend can you be your authentic self. This means that a real friend looks behind your masks and also shares the difficult times you may be going through: "I can laugh with anyone,/be myself, no trouble at all,/hang out with who I want./I can be mad at anyone I want, but there's one exception://I cry only when I'm with you./I only let go when I am with you." (The Passion Leeuwarden 2017). ${ }^{9}$

The performance made no distinction between Jesus and Peter; they sang this chorus together. Due to intertextuality, the Christological title ("messiah") from the Bible, which Peter used in the scene, and the related asymmetry between God and human beings, had in this edition of The Passion evolved into human friendship. Equally, the ecclesial implications of the biblical narrative ("rock of the church") were omitted. Additionally, the presenter called Peter Jesus' best friend forever (BFF), and Judas' jealousy of their close relationship was indicated.

Similarly, at the Last Supper, the words of institution and Judas' betrayal were integrated into a song. In this song, Jesus said goodbye to his disciples and promised he would at the same time be permanently present, which corresponds to the commemorational function of the Last Supper: "There's nothing here worth staying for./Only what was, is here./And I take that with me forever,/forever." (The Passion Leeuwarden 2017). ${ }^{10}$

Interestingly enough, the song (in Dutch) addresses a single person. This contradicts the scene in The Passion, where Jesus addressed all his disciples: "Who can explain to me how everything works,/how big the distance is between now and never?/And how it can be that I'm noticing now:/You're gone but

7 "Hier is mijn hand, hier is mijn hart,/ik geef mijn bestaan aan jou./Lang was het koud en donker, straks komt de dag,/vindt het licht zijn weg, in een nieuwe dag. ( . . . ) Er zal geen dag beginnen, dat ik niet bij jou ben./Geen uurwerk zal zinloos voor ons tikken."

8 "Je kust me, je sust me./Omhelst me, gerust me./Je vangt me, verlangt me./Oneindig ontbangt me./Je roept me, je hoort me./Je redt en verstoort me./Geloof me, beroof me./Verstikt en verdoof me./Je ademt en leeft me. ( . . ) ) Laat me los,/ik moet nu alleen./En houd me vast als het nodig is:/in gedachten. En ik zoek je/in alles om me heen."

9 "Ik kan lachen met iedereen,/mezelf zijn, geen probleem./Ik kan hangen met wie ik wil,/boos zijn op wie ik wil, met één verschil: // Ik huil alleen bij jou./Ik laat alleen bij jou mezelf gaan, alleen bij jou."

10 "Hier is niets om voor te blijven./Hier is alleen nog wat er was./En dat neem ik mee voor altijd,/voor altijd." 
are closer to me than ever before?" (The Passion Leeuwarden 2017). ${ }^{11}$ This personal address of the song supplements the communal character of the Last Supper, or rather, different interpretations of the biblical narrative are presented simultaneously: on the one hand, the shared meal as a commemorational meal, and on the other, the connectedness that an individual person feels with someone who will soon no longer be there. Because Jesus sang this song during the performance, he himself appeared as someone who is in need of such connectedness.

With the help of configured intertextuality, finally, a specific interpretation of the resurrection was presented. The risen Jesus, dressed all in white, first presented himself with open arms to Peter and then to all spectators as a helper. As he did this, he sang: "Is there anything I can do,/that will soothe your pain?/What matters to you,/it is that which I want to be." (The Passion Leeuwarden 2017). ${ }^{12}$ This performance thus stages Easter as an important event for everyone. Jesus Christ still wants to be close to people today and people who are open to his sacrifice can experience solace from him.

However, the presenter had already sung this song before, during the trial against Jesus. This creates an additional level of intertextual references, as the same text was used by different personages. Seen from this perspective, Jesus himself is dependent on help. Eventually the messiah acquires human traits.

\section{Conclusions}

In our description of The Passion as a phenomenon, we observed that it is a hybrid form of storytelling. This example of constructive public theology (Breitenberg 2003, pp. 64-65) combines modified Christian and secular elements in the context of a television broadcast. Furthermore, the hybridity is mirrored in the multi-layered reception and motivation of the people who create the event or participate in it as spectators. The audience gives the performance various meanings of its own.

The resulting plurality is supported by configured intertextuality between biblical and secular texts. Certain interpretations of the passion of Christ are presented, such as the possibility of staying connected with him through loving memory, including the Last Supper, which corresponds with the commemorational function of the Eucharist, or staying connected with him through helping each other, something which is also reflected in diaconal action. This is by no means an exhaustive list of possible interpretations of the 2017 edition.

However, other, equally biblical, approaches to Jesus' death on the cross and to the resurrection are excluded: the depiction of pain and suffering, for example, the ecclesial significance of the passion, or Jesus' death as an atoning sacrifice for the sins of the world (Hampel and Weth 2010). The broadcast nevertheless expresses traditional understandings of the passion of Christ, as we have suggested by mentioning the Eucharist and diaconia. Such traditional references to the gospel are popularized through the intertextuality with well-known songs. In addition, this connection between sacred and secular implies other, including non-theological, interpretations of the passion.

The different approaches are not only conveyed cognitively, but also emotionally. Because intertextuality is dramatically brought on stage, possible dissonances between the songs and the biblical storytelling recede into the background. Examples of these dissonances are the often diverging addressees in the Bible (collective) and in the songs (individual), labelling Jesus as messiah and as someone who, like us, needs help from friends, and the assumption that all spectators and television viewers have something in common: a supposed Dutch identity. The latter is at odds with the assumption that the audience is at least partly also Christian.

Finally, the intertextual references emphasize the human aspects of all events that occur in The Passion. The biblical story is brought down to a personal level by the music. The audience can be

\footnotetext{
11 “Wie legt me uit hoe alles werkt,/hoe groot het gat is tussen nu en nooit?/En hoe het komt dat ik nu merk:/jij bent weg, maar dichterbij dan ooit?"

12 "Is er iets wat ik doen kan,/wat je helpt in de pijn?/Wat iets voor je betekent,/wil ik graag voor je zijn."
} 
in touch with that which is performed through the songs. People can identify with the personages on stage on the basis of shared human experiences such as parting, love, hope, friendship, betrayal, solidarity, or suffering (den Braber 2012, pp. 41-43). The popular songs express these experiences. The passion play becomes a prototypical story that is accessible to everyone, even without being religious. One of the factors that enables this is configured intertextuality.

Funding: This research received no external funding.

Conflicts of Interest: The author declare no conflict of interest.

\section{References}

Andreeva, Nellie. 2015. Fox to Air 'The Passion' Live Musical about Jesus Hosted by Tyler Perry. December 15. Available online: https://www.google.com.hk/url?sa=t\&rct=j\&q=\&esrc=s\&source=web\&cd=\&ved= 2ahUKEwiyjeb5zPfsAhUZHXAKHesgAa8QFjAAegQIBRAC\&url=https\%3A\%2F\%2Fdeadline.com\% 2F2015\%2F12\%2Fthe-passion-live-musical-jesus-tyler-perry-fox-1201667399\%2F\&usg=AOvVaw10s-1YxdEmxNMuyJNtaUl (accessed on 11 November 2020).

Barton, Ulrich. 2016. eleos und compassio. Mitleid im antiken und mittelalterlichen Theater. Paderborn: Fink Wilhelm. Bernts, Ton, and Joantine Berghuijs. 2016. God in Nederland 1966-2015. Utrecht: Ten Have.

Breitenberg, E. Harold, Jr. 2003. To tell the truth. Will the real public theology please stand up? Journal of the Society of Christian Ethics 23: 55-96. [CrossRef]

Dauven-van Knippenberg, Carla. 2003. Art. Passionsspiele. In Religion in Geschichte und Gegenwart. Handwörterbuch für Theologie und Religionswissenschaft. Edited by Hans Dieter Betz, Don S. Browning, Bernd Janowski and Eberhard Jüngel. Tübingen: Mohr Siebeck, pp. 983-85.

Day, Katie, and Sebastian Kim. 2017. Introduction. In A Companion to public Theology. Brill's Companions to Modern Theology 1. Edited by Sebastian Kim and Katie Day. Leiden: Brill, pp. 1-21.

de Groot, Kees. 2015. De kerk omarmt het evenement. VPWinfo.nl Kwartaalblad van VPW Nederland 2: 16-18.

de Groot, Kees. 2019. The challenge of a church going into liquidation. Irish Theological Quarterly 84: 409-23. [CrossRef]

den Braber, Marieke. 2012. Met het evangelie de straat op. Reflectie op The Passion. Handelingen 39: 38-44.

Dillen, Annemie, and Stefan Gärtner. 2020. Discovering Practical Theology. Exploring Boundaries. Leuven, Paris and Bristol: Peeters.

Dowell, Ben. 2006. BBC's Jesus sings Heaven knows I'm miserable now. The Guardian, January 26.

Engelke, Matthew. 2012. Angels in Swindon. Public religion and ambient faith in England. American Ethnologist 39: 155-70. [CrossRef]

Fijen, Leo. 2015. Tot leven midden in de sprakeloosheid van de dood. Pasen gebeurt nog elke dag, ook in the Passion. Tijdschrift voor Liturgie 99: 36-39.

Fijen, Leo. 2020. 'The Passion' biedt troost en geeft hoop. Trouw, April 9.

Gärtner, Stefan. 2017a. Der Fall des niederländischen Katholizismus. Kirche und Seelsorge in einer spätmodernen Gesellschaft. Freiburg/Br., Basel and Wien: Herder.

Gärtner, Stefan. 2017b. The Passion. Über eine hybride Form des Passionsspiels. Liturgisches Jahrbuch 67: 237-52.

Hampel, Volker, and Rudolf Weth, eds. 2010. Für uns gestorben. Sühne-Opfer-Stellvertretung. Neukirchen-Vluyn: Neukirchener Verlag.

Hoondert, Martin, and Mirella Klomp. 2014. “The streets of Gouda are our Jerusalem!” A popular passion performed in the market square of a Dutch city. In Sacred Spaces and Contested Identities. Space and Ritual Dynamics in Europe and Africa. Edited by Wouter E. A. van Beek, Paul Post and Philip Nel. Trenton: Africa World Press, pp. 313-30.

Jansen, Mathilde. 2017. Op zoek naar een nieuwe definitie van religie. Nieuwsbrief Meertens Instituut, September 8. Klomp, Mirella, and Danie Veldsman. 2017. After god but behind the cross. The procession as a way to re-encounter god in a culture beyond classical liturgy. Studia Liturgica 47: 15-29. [CrossRef]

Klomp, Mirella, and Marcel Barnard. 2017. Sacro-Soundscapes. Interpreting contemporary ritual performances of sacred music through the case of The Passion in the Netherlands. International Journal of Practical Theology 21: 240-58. [CrossRef] 
Klomp, Mirella, Marten van der Meulen, Erin Wilson, and A. Zijdemans. 2018. The Passion as public reflexivity. How the Dutch in a ritual-musical event reflect on religious and moral discussions in society. Journal of Religion in Europe 11: 195-221. [CrossRef]

Klomp, Mirella, and Marten van der Meulen. 2017. The Passion as ludic practice-Understanding public ritual performances in late modern society: A case study from the Netherlands. Journal of Contemporary Religion 32: 387-401. [CrossRef]

Klomp, Mirella. 2012. Moderne liturgie, stadsmarketing of heiligschennis? The Passion vanuit cultureel-antropologisch perspectief. Handelingen 39: 45-54.

Klomp, Mirella. 2015a. Staging the resurrection. The public theology of Dutch production and broadcasting companies. International Journal of Public Theology 9: 446-64. [CrossRef]

Klomp, Mirella. 2015b. The Passion met God als optie. Kerk en Theologie 66: 134-40.

Korthaus, Michael. 2007. Kreuzestheologie. Geschichte und Gehalt eines Programmbegriffs in der evangelischen Theologie. Tübinge: Mohr Siebeck.

Koster, Koert. 2017. Gib Mir doch deine Angst. Ich schenke dir Mut und Hoffnung dafür. Mijnbestseller.nl: Rotterdam.

Kristeva, Julia. 1972. Probleme der Textstrukturation. In Strukturalismus in der Literaturwissenschaft. Edited by Heinz Blumensath. Köln: Kiepenheuer \& Witsch, pp. 243-62.

Mediacourant. 2017. The Passion Voor Vierde jaar op rij Door 3-Miljoengrens. April 14. Available online: https://www.mediacourant.nl/2017/04/the-passion-voor-vierde-jaar-op-rij-door-3-miljoengrens/ (accessed on 11 November 2020).

Mediacourant. 2020. Door Corona Toegetakeld The Passion Toch Kijkcijferhit. April 10. Available online: https://www.mediacourant.nl/2020/04/door-corona-toegetakeld-the-passion-toch-kijkcijferhit/ (accessed on 11 November 2020).

Moser, Dietz-Rüdiger. 1990. Die Bühnenformen der Passionsspiele. Eine Skizze. In Hört, Sehet, Weint und Liebt. Passionsspiele im Alpenländischen Raum. Edited by Michael Henker, Eberhard Dünninger and Evamaria Brockhoff. München: Süddeutscher Verlag, pp. 95-111.

Nelissen, Klaus. 2020. Dolorosa statt Dschungelcamp. Herder Korrespondenz 74: 13-15.

Polheim, Karl Konrad. 2006. Art. Liturgische Spiele, liturgisches Drama. Lexikon für Theologie und Kirche 6: 1005-6. Schneider, Michael. 2018. Art. Intertextualität. In Wissenschaftlich-Religionspädagogisches Lexikon im Internet (WiReLex). Edited by Mirjam Zimmermann and Heike Lindner. Stuttgart: Deutsche Bibelgesellschaft.

Schulze, Ursula. 2012. Geistliche Spiele im Mittelalter und in der Frühen Neuzeit. Von der liturgischen Feier zum Schauspiel. Berlin: Erich Schmidt Verlag.

Schütz, Alfred. 2020. Strukturen der Lebenswelt. Alfred Schütz Werkausgabe Band IX. Herausgegeben von Martin Endreß und Sebastian Klimasch. Köln: Herbert von Halem Verlag.

Stassen, Petra, and Ad van der Helm. 2016. God is verhuisd. Naar nieuwe gelovige gemeenschappen. Berne: Abdij van Berne. 't Mannetje, Chris. 2015. De Goede Week reconsidered. VPWinfo.nl Kwartaalblad van VPW Nederland 2: 4-6.

The Passion Leeuwarden. 2017. Complete Songteksten 2017. Available online: https://visie.eo.nl/artikel/2017/04/ alle-teksten-van-de-liedjes-uit-the-passion-leeuwarden (accessed on 11 November 2020).

van den Hemel, Ernst. 2020. Passie voor de passie. De Matthäus, The Passion en Andere Passiespelen in Ontkerkelijkt Nederland. Utrecht: Ten Have.

van der Meulen, Marten. 2017. Het succes van The Passion verklaard. pthu.nl/Bijbelblog, April 13.

von Fischer, Kurt. 1997. Die Passion. Musik zwischen Kunst und Kirche. Kassel: Bärenreiter Verlag.

Publisher's Note: MDPI stays neutral with regard to jurisdictional claims in published maps and institutional affiliations.

(C) 2020 by the author. Licensee MDPI, Basel, Switzerland. This article is an open access article distributed under the terms and conditions of the Creative Commons Attribution (CC BY) license (http://creativecommons.org/licenses/by/4.0/). 